\title{
Aluminosilicates at different levels in rye litter and feed affect the growth and meat quality of broiler chickens
}

\author{
Mirosław Banaszak $^{1}$ (D) Jakub Biesek ${ }^{1}$ (D) Marek Adamski $^{1}$ (D)
}

Received: 29 June 2021 / Accepted: 27 August 2021 / Published online: 3 September 2021

(c) The Author(s) 2021

\begin{abstract}
Litter sanitation treatments and feed supplements that stimulate bird growth. The aim of this study was to analyse the effects of zeolite (z) and halloysite (h) in feed and rye straw litter on growth performance, meat quality in chickens. 500 males Ross 308 were allocated to 5 groups (10 replicates). Feed for groups 2-5 was supplemented with halloysite and zeolite (25:75). The content of aluminosilicates in the feed was different depending on the feeding phase: $0.5,1,1.5$, or $2 \%$. The following doses were used in litter: $2,0.800 \mathrm{~kg} / \mathrm{m}^{2} \mathrm{~h} ; 3,0.400 \mathrm{~kg} / \mathrm{m}^{2} \mathrm{~h}$ and $0.400 \mathrm{~kg} / \mathrm{m}^{2} \mathrm{z} ; 4,0.800 \mathrm{~kg} / \mathrm{m}^{2} \mathrm{z} ; 5,0.200 \mathrm{~kg} / \mathrm{m}^{2} \mathrm{~h}$, and $0.600 \mathrm{~kg} / \mathrm{m}^{2} \mathrm{z}$. Growth, and meat quality were analysed. Body weight and body weight gain were higher in groups $2-5$ than in group 1, while feed intake was lower in groups 1 and $2(p<0.05)$. Body weight, the weight of carcass, and most of its elements were higher in the experimental groups $(p<0.05)$. Breast muscles from group 1 were characterised by better water-holding capacity and higher protein content, while those from 4 had higher content of collagen and water $(p<0.05)$. Breast muscles from group 3 were characterized by lower yellowness than in $2(p<0.05)$. Leg muscles from group 1 were characterized by lower redness than in $4(p<0.05)$. Water-holding capacity was better in group 3 and protein content was higher in $2(p<0.05)$. The content of fat in leg muscle was lower in all experimental groups compared to control $(p<0.05)$. This indicates the suitability of aluminosilicates in poultry management practice, with better growth and meat quality.
\end{abstract}

Keywords Broiler $\cdot$ Rye litter $\cdot$ Zeolite $\cdot$ Halloysite $\cdot$ Growth $\cdot$ Meat quality

\section{Introduction}

Dynamically growing poultry industry is facing new challenges associated with the health of birds, and effective production and delivery of good quality safe meat, free from antibiotic residues (Hafez and Attia 2020). The issue of antibiotics use in animal production concerns many countries where restrictions are introduced, but antibiotics can be replaced with alternative agents improving production performance and meat quality, as

Jakub Biesek

jakub.biesek@utp.edu.pl

Mirosław Banaszak

miroslaw.banaszak@utp.edu.pl

Marek Adamski

adamski@utp.edu.pl

1 Department of Animal Breeding and Nutrition, Faculty of Animal Breeding and Biology, Bydgoszcz University of Science and Technology, Mazowiecka 28, Bydgoszcz 85-084, Poland well as the biosecurity on poultry farms (Selaledi et al. 2020). The safety of production is also related to animal welfare, which allows for the rearing of a healthy flock, and thus production of good quality meat (Iannetti et al. 2020). The antibiotic-free production of broiler chickens is challenging for many reasons, including consumer expectations, bird quality and environmental impact, and the most popular alternative agents are probiotics, prebiotics, and enzymes (Haque et al. 2020). As concluded by other authors (Haque et al. 2020; Roth et al. 2019), alternatives should ensure an appropriate volume of production, ensure consumer health and environmental protection, and therefore the search is focused on natural agents with beneficial effects on the animal body. An interesting solution may be aluminosilicates (natural zoelites), which are used in two areas: as agents ensuring good sanitary conditions, and as a feed additive to improve growth performance and meat quality (Andronikashvili et al. 2014). Aluminosilicates are natural minerals adsorbing ammonia and mycotoxins, which improves the quality and biosecurity of poultry production (Huff et al. 1992; Wlazło et al. 2016). 
Schneider et al. (2017) reported that the addition of zeolites in the diet of laying hens improved egg quality and had a positive effect on the growth performance of broiler chickens, as well as on the quality of their litter and even intestinal health. Natural zeolites added to feed and litter $(5 \mathrm{~g} / \mathrm{kg}$ of feed; $100 \mathrm{~g} / \mathrm{kg}$ of litter) when used alone had no effect on growth performance or dressing percentage (Schneider et al. 2006). Halloysite is less popular, but research was conducted on the use of this mineral as an agent reducing odour emissions in poultry production, and the results revealed its beneficial effects (Korczyński et al. 2013). According to Shariatmadari (2008), findings on the positive effect of zeolites on the quality of production of broiler chickens are inconclusive, but there are some implications supporting this solution with respect to the sanitary conditions on poultry farms and the growth of chickens. These authors also suggested that doses of aluminosilicates should be adjusted with consideration of the production system, type of litter, and even the age and sex of birds. The available literature on the effects of aluminosilicates in feed and litter on meat quality in broiler chickens is limited, especially with respect to their combined use, so studies in this area seem to be fully justified.

\section{Material and methods}

The aim of this study was to analyse and compare the effects of aluminosilicates in feed and chopped rye straw litter on growth performance, carcass traits, physicochemical parameters, and meat quality in broiler chickens reared on a large poultry farm.

The presented research is part of a project "Safe Farm - innovative products, processes and marketing in the production of broiler chickens", implemented in 2020-2022 and co-financed from the European Agricultural Fund for Rural Development: Europe investing in rural areas" in cooperation with the Agency for Restructuring and Modernisation of Agriculture (Poland).

The study concerned the analysis of physicochemical characteristics of meat quality obtained from broiler chickens managed on a commercial farm. Growth performance was controlled by the farm owner in cooperation with the research team. Therefore, according to Directive no. 2010/63/EU, the study did not require approval from a Local Ethics Committee. No approval was required under Resolution no. 13/2016 of the National Ethics Committee for Animal Experiments of 17 June 2016. Slaughter of birds was done according to the Council Regulation (EC) No 1099/2009 of 24 September 2009 on the protection of animals at the time of the killing. All methods in the presented experiment were carried out in accordance with relevant guidelines and regulations.

\section{Bird management}

The study was carried out on a large commercial broiler chicken farm. A separate experimental zone was established in a farm building, stocked with 500 Ross 308 broiler chickens assigned to 5 equal-size groups, in 10 replicates per group (10 birds per group). The separate experimental zone indicates that the studies were conducted according to standards in poultry experiments and the intended purpose was to indicate that the experiment was conducted on a large farm to demonstrate the nature of the $\mathrm{R}+\mathrm{D}$ studies, in collaboration with broiler chicken producers. The study site had no effect on any disorders and rearing was fully controlled. The management of broiler chickens was compliant with relevant standards and recommendations (Aviagen 2015). Birds were kept on chopped rye straw litter for 42 days. In the study, litter material in the form of rye straw litter was used due to its universality and general availability from the point of view of poultry producers. The use of the addition of aluminosilicates is a response to the search for methods to raise standards in poultry production, which is currently related to the trend of using natural resources, taking into account the cost-effectiveness. Group 1 was the control, where standard management was applied without experimental factors. Groups 2-5 received different levels of aluminosilicates (halloysite and zeolite) in feed and litter. Chicken diet was based on commercially available feed and consisted of 4 feeding phases: starter, grower 1, grower 2 and finisher. Feed for groups $2-5$ was supplemented with halloysite and zeolite in the proportion 25:75. The content of aluminosilicates in the feed was different depending on the feeding phase: $0.5,1,1.5$, or $2 \%$ (phases 1 to 4 ). Characteristics of groups and data on the addition of aluminosilicates in feed and litter are presented in Table 1. The basic chemical composition of feed for the control and experimental groups in each feeding phase is presented in Table 2. The feeds were purchased from commercial companies producing feeds for broiler chickens. The chemical composition declared for the applied mixtures fully corresponds to the Ross 308 chicken feeding standards, and the data presented in the Table 2 are analytical. The feeds were iso-protein and isocaloric. The aluminosilicates were added to the feed at the factory level of the feed company. The feed was in the form of granules. The test additive was mixed in the feed pellets. The chemical composition and physical properties of zeolite are described in the work of Biesek et al. (2021). In the presented work and in the cited source, aluminosilicates from the same supplier were used. Zeolite characterized 
Table 1 Description of broiler chickens used in the experiment

\begin{tabular}{lllll}
\hline Group no & $n$ birds & $\begin{array}{l}\text { Replicates }(\text { pen } x \\
\text { birds) }\end{array}$ & Addition in litter* $\left(\mathrm{kg} / \mathrm{m}^{2}\right)$ & Addition in feed \\
\hline 1 & $10 \times 10$ & None & None \\
2 & 100 & $10 \times 10$ & $0.800 \mathrm{~h}^{1}$ & halloysite and zeolite to feed in proportion $25: 75 ;$ \\
3 & 100 & $10 \times 10$ & $0.400 \mathrm{~h} / 0.400 \mathrm{z}^{2}$ & starter, $0.5 \%$; grower $1,1 \% ;$ grower $2,1.5 \% ;$ \\
4 & 100 & $10 \times 10$ & $0.800 \mathrm{~h}$ & finisher, $2 \%$ \\
5 & 100 & $10 \times 10$ & $0.200 \mathrm{~h} / 0.600 \mathrm{z}$ & \\
\hline
\end{tabular}

${ }^{1,}$ h, halloysite; ${ }^{2}$, z, zeolite

*, weight per treatment; aluminosilicates were applied on 5 dates: days 1, 10, 20, 30, 35 of rearing

with a specific surface area of $30-60 \mathrm{~m}^{2} / \mathrm{g}$, a bulk density of $1.60-1.80 \mathrm{~kg} / \mathrm{m}^{3}$, and weight of $2.20-2.44 \mathrm{~kg} / \mathrm{m}^{3}$. Silicon dioxide $\left(\mathrm{SiO}_{2}, 65-71.30 \%\right)$ and aluminium oxide $\left(\mathrm{Al}_{2} \mathrm{O}_{3}, 11.50-13.10 \%\right)$ were marked. Zeolite contains calcium oxide $(\mathrm{CaO}, 2.70-5.20 \%)$, potassium oxide $\left(\mathrm{K}_{2} \mathrm{O}\right.$, $2.20-3.40 \%)$, iron (III) oxide $\left(\mathrm{Fe}_{2} \mathrm{O}_{3}, 0.70-1.90 \%\right)$, magnesium oxide ( $\mathrm{MgO}, 0.60-1.20 \%)$, sodium oxide $\left(\mathrm{Na}_{2} \mathrm{O}\right.$, $0.20-1.30 \%)$, titanium oxide $\left(\mathrm{TiO}_{2}, 0.10-0.30 \%\right)$, and $4.80-5.40 \%$ of Si/Al. Zeolite also contained minerals such as clinoptilolite (84\%), cristobalite $(8 \%)$, mica clay $(4 \%)$, plagioclase (3-4\%), rutile $(0.10-0.30 \%)$, and traces of quartz. Halloysite composition contains $13.00 \%$ aluminium ( $\mathrm{Al}), 12.00 \%$ silicon $(\mathrm{Si}), 0.40 \%$ calcium $(\mathrm{Ca})$, $0.30 \%$ magnesium $(\mathrm{Mg}), 0.10 \%$ sodium $(\mathrm{Na}), 0.08 \%$ potassium $(\mathrm{K}), 0.30 \%$ phosphorus $(\mathrm{P}), 9.00 \%$ iron $(\mathrm{Fe}), 1.00 \%$ titanium (Ti), and $0.20 \%$ manganese $(\mathrm{Mn})$. The specific surface area of halloysite is $65-85 \mathrm{~m}^{2} / \mathrm{g}$ and the bulk density is $0.70-0.85 \mathrm{~g} / \mathrm{cm}^{3}$. Zeolite and halloysite added to the litter were in a powdery, dusty form.

\section{Growth performance}

Body weight (BW) was measured on 5 dates of production: at stocking (day 1), and on days 10, 22, 35, and 42 (slaughter). We also recorded daily feed intake (FI) for each replicate in 5 groups, for each of the four feeding phases. Recorded data were used for the calculation of body weight gain (BWG) and feed conversion ratio per kg of body weight gain (FCR).

\section{Sample collection and meat quality analysis}

After the rearing was completed, randomly selected chickens were slaughtered. The birds were starved for $12 \mathrm{~h}$, and 10 birds from each group were selected. In order to identify the chickens, jiffy bands with ID numbers were attached to the wings. The birds were stunned with an electric current (loss of consciousness), and slaughtered by decapitation at the atlanto-occipital joint (rapid exsanguination). The carcasses were scalded in warm water at $60-65{ }^{\circ} \mathrm{C}$, which allowed for the removal of all feathers. Feet were cut off at the ankle joints. Carcasses were gutted, and edible offal (heart, stomach, liver) were kept for further analyses.

The $\mathrm{pH}$ value of muscles was measured 45 min postmortem $\left(\mathrm{pH}_{45 \min }\right)$ using a $\mathrm{pH}$-meter with a knife electrode (Elmetron, Zabrze, Poland) inserted in the greater pectoral muscle (pectoralis major muscle) at a depth of $2 \mathrm{~cm}$. Carcasses were chilled and placed in a cold room (Hendi, Poznań, Poland) for $24 \mathrm{~h}$ at $4{ }^{\circ} \mathrm{C}$.

After $24 \mathrm{~h}$ the $\mathrm{pH}$ of muscles $\left(\mathrm{pH}_{24 \text { hours }}\right)$ was measured again and the carcasses and edible offal were weighed (Radwag, Radom, Poland). Carcasses were dissected by separating the neck with skin, wings with skin, skin with subcutaneous fat, abdominal fat, breast muscles, leg muscles (thighs and drumsticks; without bones) and carcass remains
Table 2 Analytical composition of feeds for broiler chickens, 4 feeding phases

\begin{tabular}{|c|c|c|c|c|c|c|c|c|}
\hline \multirow[t]{2}{*}{ Constituent [\%] } & \multicolumn{2}{|c|}{ STARTER } & \multicolumn{2}{|c|}{ GROWER 1} & \multicolumn{2}{|c|}{ GROWER 2} & \multicolumn{2}{|c|}{ FINISHER } \\
\hline & $\mathrm{C}(1)^{1}$ & $E(2-5)^{2}$ & $\mathrm{C}(1)$ & $\mathrm{E}(2-5)$ & $\mathrm{C}(1)$ & $\mathrm{E}(2-5)$ & $\mathrm{C}(1)$ & $\mathrm{E}(2-5)$ \\
\hline Dry matter & 88.70 & 87.74 & 88.85 & 89.25 & 89.24 & 88.58 & 88.61 & 88.71 \\
\hline Crude ash & 7.74 & 7.52 & 5.51 & 5.12 & 5.31 & 5.57 & 5.13 & 5.86 \\
\hline Crude protein & 20.75 & 21.17 & 19.96 & 21.92 & 19.37 & 20.03 & 18.30 & 18.76 \\
\hline Crude fat & 5.08 & 5.68 & 6.51 & 7.51 & 7.84 & 7.08 & 7.93 & 6.99 \\
\hline Crude fibre & 2.39 & 2.88 & 3.01 & 3.70 & 3.21 & 3.70 & 3.18 & 3.44 \\
\hline Starch & 39.50 & 38.43 & 39.13 & 37.78 & 38.82 & 37.78 & 40.38 & 39.48 \\
\hline
\end{tabular}

1, $\mathrm{C}(1)$, control group; ${ }^{2}, \mathrm{D}(2-5)$, experimental groups. Feed was commercial. Data is only analytical 
(body and leg bones). All separated elements were weighed. Breast and leg muscles were used for further analyses. The colour of the right breast and leg muscles was analysed on the outer side of the muscles using a colorimeter CR400 (Konica Minolta, Tokyo, Japan) and the CIE (International Commission on Illumination) system (Martinez et al. 2020). For calibration the white calibration plate no. 21033065 and the $\mathrm{D}_{65} \mathrm{Y}_{86 \cdot 1} \mathrm{x}_{0.3188} \mathrm{y}_{0.3362}$ scale were used. Lightness $\left(\mathrm{L}^{*}\right)$, redness $\left(\mathrm{a}^{*}\right)$, and yellowness $\left(\mathrm{b}^{*}\right)$ were analysed. After colour assessment, the right breast muscles were weighed and placed in plastic bags with a zip closure to analyse drip loss (loss of water in \%) with minor modifications (Xing et al. 2020). The left breast and leg muscles from each group were disintegrated in a mincer (Hendi, Poznań, Poland). The water-holding capacity of minced muscles was analysed according to a procedure described by Biesek et al. (2020), and the initial weight of each sample was $0.300 \mathrm{~g} \pm 0.005 \mathrm{~g}$. The final measurement indicated the loss of water in percent. Additionally, the chemical composition of minced meat samples $(90 \mathrm{~g})$ was analysed using spectrometry (FoodScan, FOSS, Hilleroed, Denmark) and near infrared transmission (NIR) (Mendonca et al. 2020). The listed characteristics were tested for each of the selected birds.

\section{Statistical analysis}

Obtained data were analysed with statistical software (Statistica Statsoft 2017). Means for each analysed trait were calculated for each treatment with standard deviation $( \pm S D)$. The standard error of the mean (SEM) in total was calculated. The one-way ANOVA model was used to analyse variance. Differences in the values of the examined traits for each group were calculated. The significance of differences was verified using the post-hoc Tukey test. Analysis was performed using the one-way ANOVA model with consideration of the effects of subclasses. Differences were considered significant at $p<0.05$. The experimental unit in the calculation of growth performance was replication of groups ( $10 \times 10$ birds). On the other hand, in the analyses of carcasses and meat quality, selected birds from each group were used in the amount allowing for statistical calculations. The number of birds used in the laboratory work is acceptable standard for poultry research.

\section{Results}

\section{Growth performance}

The losses of broiler chickens were controlled and recorded, but they did not exceed $1 \%$ in the flock. It was related to weak chicks at the beginning of rearing. The study revealed significantly higher body weight of broiler chickens in groups 3,4 and 5 (LITTER: $3,0.400 \mathrm{~kg} / \mathrm{m}^{2}$ of halloysite and $0.400 \mathrm{~kg} / \mathrm{m}^{2}$ of zeolite; $4,0.800 \mathrm{~kg} / \mathrm{m}^{2}$ of zeolite; 5 , $0.200 \mathrm{~kg} / \mathrm{m}^{2}$ of halloysite and $0.600 \mathrm{~kg} / \mathrm{m}^{2}$ of zeolite; FEED: $3-5$, proportion $25: 75$ of halloysite and zeolite, $0.5-2 \%$ in feed) compared to the control group (1) on day 22 , and in groups 3-5 and 2 on days 35 and 42 (LITTER: 2, $0.800 \mathrm{~kg}$ / $\mathrm{m}^{2}$ of halloysite in litter; FEED: proportion 25:75 of halloysite and zeolite, $0.5-2 \%$ in feed) compared to group 1 $(p<0.05)$. The analysis of data on body weight gain showed significantly higher gains in groups $2-5$ compared to group 1 on days $11-22,23-35$, and $36-42$, and in the whole production period (days 1-42) $(p<0.05)$. Feed intake was significantly lower in group 1 compared to experimental groups, and for the whole production period it was highest in group $5(p<0.05)$. Feed conversion ratio (FCR) was significantly higher in group 5 compared to other groups on days 11-22, and in group 1 on days $23-35(p<0.05)$. No significant differences were found for other analysed growth performance parameters presented in Table $3(p>0.05)$.

\section{Carcass traits}

Table 4 presents data on carcass traits. Body weight and carcass weight in broiler chickens selected for slaughter were significantly higher in groups $2-5$ than in group $1(p<0.05)$. Dressing percentage was significantly lower in group 4 compared to groups 1 and $5(p<0.05)$. The weight of neck with skin, wings, heart, liver and carcass remains (body and leg bones) were significantly higher in the experimental groups $(2-5)$ compared to the control group $(1)(p<0.05)$. No significant differences were found for other analysed traits $(p>0.05)$.

Table 5 presents data on the content of muscles and fat in broiler chicken carcass. The weight of breast muscles, leg muscles and total muscles (breast + leg) was significantly higher in the experimental groups compared to group 1. Moreover, the proportion of breast muscles in carcass was significantly higher in groups 2 and 3 compared to the control group $(p<0.05)$. The weight of skin with subcutaneous fat was significantly higher in groups 2 and 3 than in group 1 , and its proportion in carcass and the proportion of total fat was significantly lower in group 4 than in group $1(p<0.05)$. The weight of total fat in the control group was significantly lower than in groups 2 and $5(p<0.05)$. In the Tables 2 and 3 , the weight of individual elements, which may differ due to significant differences in the body weight of the birds, therefore the percentage share of the elements was shown for a more detailed analysis of the obtained results.

\section{Meat quality}

The value of $\mathrm{pH}_{45 \min }$ was significantly lower in group 3, where zeolite and halloysite were used in litter in a 1:1 
Table 3 Growth performance of broiler chickens during the 42 days of rearing

\begin{tabular}{|c|c|c|c|c|c|c|c|}
\hline \multirow{2}{*}{$\begin{array}{l}\text { Parameter } \\
N=100\end{array}$} & \multicolumn{5}{|l|}{ Group $^{1}$} & \multirow[t]{2}{*}{ SEM } & \multirow[t]{2}{*}{ Significance } \\
\hline & 1 & 2 & 3 & 4 & 5 & & \\
\hline \multicolumn{8}{|l|}{ BW (g) } \\
\hline \multirow[t]{2}{*}{ 1-day old chicks } & 43.83 & 44.10 & 42.80 & 43.92 & 42.89 & 0.20 & NS \\
\hline & \pm 1.24 & \pm 1.60 & \pm 1.60 & \pm 1.31 & \pm 0.98 & & \\
\hline \multirow[t]{2}{*}{ day 10} & 379.44 & 387.56 & 387.56 & 381.85 & 381.85 & 2.07 & NS \\
\hline & \pm 6.36 & \pm 11.16 & \pm 25.56 & \pm 16.24 & \pm 6.46 & & \\
\hline \multirow[t]{2}{*}{ day 22} & $1213.84^{\mathrm{b}}$ & $1285.40^{\mathrm{ab}}$ & $1294.27^{\mathrm{a}}$ & $1289.96^{\mathrm{a}}$ & $1289.18^{\mathrm{a}}$ & 8.14 & $<0.05$ \\
\hline & \pm 36.70 & \pm 31.91 & \pm 70.21 & \pm 69.21 & \pm 28.13 & & \\
\hline \multirow[t]{2}{*}{ day 35} & $2095.00^{\mathrm{b}}$ & $2423.92^{\mathrm{a}}$ & $2472.66^{\mathrm{a}}$ & $2476.85^{\mathrm{a}}$ & $2471.70^{\mathrm{a}}$ & 27.60 & $<0.05$ \\
\hline & \pm 128.74 & \pm 69.54 & \pm 136.96 & \pm 190.18 & \pm 101.11 & & \\
\hline \multirow[t]{2}{*}{ day 42} & $2348.79^{\mathrm{b}}$ & $2867.59^{\mathrm{a}}$ & $2970.348^{\mathrm{a}}$ & $2993.83^{\mathrm{a}}$ & $2996.03^{\mathrm{a}}$ & 40.52 & $<0.05$ \\
\hline & \pm 161.94 & \pm 86.78 & \pm 185.20 & \pm 130.14 & \pm 144.43 & & \\
\hline \multicolumn{8}{|l|}{ BWG (g) } \\
\hline \multirow[t]{2}{*}{ days $1-10$} & 335.61 & 343.46 & 339.05 & 338.30 & 338.96 & 2.01 & NS \\
\hline & \pm 6.54 & \pm 10.21 & \pm 25.12 & \pm 15.70 & \pm 6.15 & & \\
\hline \multirow[t]{2}{*}{ days $11-22$} & $834.39^{b}$ & $897.84^{\mathrm{a}}$ & $912.42^{\mathrm{a}}$ & $907.74^{\mathrm{a}}$ & $907.33^{\mathrm{a}}$ & 6.92 & $<0.05$ \\
\hline & \pm 34.36 & \pm 26.64 & \pm 51.40 & \pm 56.09 & \pm 24.95 & & \\
\hline \multirow[t]{2}{*}{ days $23-35$} & $882.06^{\mathrm{b}}$ & $1138.39^{\mathrm{a}}$ & $1178.39^{\mathrm{a}}$ & $1186.90^{\mathrm{a}}$ & $1182.52^{\mathrm{a}}$ & 20.98 & $<0.05$ \\
\hline & \pm 100.49 & \pm 50.06 & \pm 90.81 & \pm 126.80 & \pm 81.88 & & \\
\hline \multirow[t]{2}{*}{ days $36-42$} & $252.89^{b}$ & $443.67^{\mathrm{a}}$ & $497.68^{\mathrm{a}}$ & $516.97^{\mathrm{a}}$ & $524.32^{\mathrm{a}}$ & 18.10 & $<0.05$ \\
\hline & \pm 102.64 & \pm 64.75 & \pm 64.51 & \pm 78.72 & \pm 85.31 & & \\
\hline \multirow[t]{2}{*}{ days $1-42$} & $2304.96^{\mathrm{b}}$ & $2823.49^{\mathrm{a}}$ & $2927.55^{\mathrm{a}}$ & $2949.91^{\mathrm{a}}$ & $2953.14^{\mathrm{a}}$ & 40.52 & $<0.05$ \\
\hline & \pm 162.03 & \pm 86.10 & \pm 184.42 & \pm 130.01 & \pm 145.87 & & \\
\hline \multicolumn{8}{|l|}{ FI (g; per bird) } \\
\hline \multirow[t]{2}{*}{ days $1-10$} & 343.35 & 353.76 & 370.51 & 361.43 & 335.32 & 4.09 & NS \\
\hline & \pm 17.62 & \pm 28.23 & \pm 35.40 & \pm 26.03 & \pm 25.43 & & \\
\hline \multirow[t]{2}{*}{ days $11-22$} & $935.04^{c}$ & $1006.87^{\mathrm{b}}$ & $1013.70^{\mathrm{b}}$ & $1010.94^{\mathrm{b}}$ & $1110.71^{\mathrm{a}}$ & 10.08 & $<0.05$ \\
\hline & \pm 32.64 & \pm 37.82 & \pm 36.13 & \pm 62.53 & \pm 50.70 & & \\
\hline \multirow[t]{2}{*}{ days $23-35$} & $1605.53^{c}$ & $1759.67^{\mathrm{b}}$ & $1813.40^{\mathrm{ab}}$ & $1864.13^{\mathrm{ab}}$ & $1892.82^{\mathrm{a}}$ & 18.95 & $<0.05$ \\
\hline & \pm 111.60 & \pm 71.44 & \pm 91.90 & \pm 80.23 & \pm 89.78 & & \\
\hline \multirow[t]{2}{*}{ days $36-42$} & $508.33^{\mathrm{b}}$ & $810.73^{a}$ & $800.16^{\mathrm{a}}$ & $873.67^{\mathrm{a}}$ & $860.60^{\mathrm{a}}$ & 20.89 & $<0.05$ \\
\hline & \pm 68.15 & \pm 66.06 & \pm 40.94 & \pm 46.24 & \pm 77.47 & & \\
\hline \multirow[t]{2}{*}{ days $1-42$} & $3541.02^{\mathrm{c}}$ & $3938.02^{\mathrm{b}}$ & $4170.21^{\mathrm{ab}}$ & $4210.69^{\mathrm{ab}}$ & $4312.98^{\mathrm{a}}$ & 50.30 & $<0.05$ \\
\hline & \pm 213.23 & \pm 138.35 & \pm 301.86 & \pm 240.00 & \pm 230.99 & & \\
\hline FCR (kg/kg) & & & & & & & \\
\hline days $1-10$ & 1.03 & 1.03 & 1.10 & 1.07 & 0.99 & 0.01 & NS \\
\hline & \pm 0.05 & \pm 0.10 & \pm 0.16 & \pm 0.07 & \pm 0.07 & & \\
\hline days $11-22$ & $1.12^{\mathrm{b}}$ & $1.12^{\mathrm{b}}$ & $1.11^{\mathrm{b}}$ & $1.11^{\mathrm{b}}$ & $1.22^{\mathrm{a}}$ & 0.01 & $<0.05$ \\
\hline & \pm 0.04 & \pm 0.04 & \pm 0.04 & \pm 0.08 & \pm 0.06 & & \\
\hline days $23-35$ & $1.84^{\mathrm{a}}$ & $1.55^{\mathrm{b}}$ & $1.55^{\mathrm{b}}$ & $1.58^{\mathrm{b}}$ & $1.60^{\mathrm{b}}$ & 0.03 & $<0.05$ \\
\hline & \pm 0.23 & \pm 0.07 & \pm 0.12 & \pm 0.14 & \pm 0.10 & & \\
\hline days $36-42$ & 2.36 & 1.85 & 1.62 & 1.72 & 1.67 & 0.08 & NS \\
\hline & \pm 1.16 & \pm 0.23 & \pm 0.15 & \pm 0.29 & \pm 0.24 & & \\
\hline days $1-42$ & 1.54 & 1.39 & 1.42 & 1.43 & 1.46 & 0.02 & NS \\
\hline & \pm 0.17 & \pm 0.03 & \pm 0.12 & \pm 0.09 & \pm 0.07 & & \\
\hline
\end{tabular}

a,b..., means in the same line with no common superscript differ between groups $(p<0.05)$; NS, no significance; \pm SD, standard deviation; SEM, standard error of the mean for all data; ${ }^{1}, 1$, no addition of aluminosilicates to feed or litter; $2,0.800 \mathrm{~kg} / \mathrm{m}^{2}$ of halloysite in litter; 3 , $0.400 \mathrm{~kg} / \mathrm{m}^{2}$ of halloysite and $0.400 \mathrm{~kg} / \mathrm{m}^{2}$ of zeolite in litter; $4,0.800 \mathrm{~kg} / \mathrm{m}^{2}$ of zeolite in litter; $5,0.200 \mathrm{~kg} / \mathrm{m}^{2}$ of halloysite and $0.600 \mathrm{~kg} / \mathrm{m}^{2}$ of zeolite in litter; groups 2-5, addition of halloysite and zeolite to feed (proportion 25:75; starter, 0.5\%; grower 1, $1 \%$; grower $2,1.5 \%$; finisher, $2 \%){ }^{2}$, BW, body weight, g; BWG, body weight gain, g; FI, feed intake, g; FCR, feed conversion ratio, $\mathrm{kg} / \mathrm{kg}$ 
Table 4 Traits of broiler chicken meat

\begin{tabular}{|c|c|c|c|c|c|c|c|}
\hline \multirow{2}{*}{$\begin{array}{l}\text { Parameter } \\
n=10\end{array}$} & \multicolumn{5}{|l|}{ Group $^{1}$} & \multirow[t]{2}{*}{ SEM } & \multirow[t]{2}{*}{ Significance } \\
\hline & 1 & 2 & 3 & 4 & 5 & & \\
\hline Pre-slaughter body weight (g) & $\begin{array}{l}2211.50^{b} \\
\pm 198.02\end{array}$ & $\begin{array}{l}3105.30^{\mathrm{a}} \\
\pm 132.63\end{array}$ & $\begin{array}{l}3109.00^{\mathrm{a}} \\
\pm 235.19\end{array}$ & $\begin{array}{l}3249.10^{\mathrm{a}} \\
\pm 131.10\end{array}$ & $\begin{array}{l}3092.90^{\mathrm{a}} \\
\pm 119.84\end{array}$ & 58.34 & $<0.05$ \\
\hline Weight of carcass ( $\mathrm{g}$ ) & $\begin{array}{l}1734.27^{b} \\
\pm 161.56\end{array}$ & $\begin{array}{l}2390.38^{\mathrm{a}} \\
\pm 99.70\end{array}$ & $\begin{array}{l}2346.22^{\mathrm{a}} \\
\pm 204.15\end{array}$ & $\begin{array}{l}2416.75^{\mathrm{a}} \\
\pm 110.39\end{array}$ & $\begin{array}{l}2354.88^{\mathrm{a}} \\
\pm 95.60\end{array}$ & 41.55 & $<0.05$ \\
\hline Dressing percentage $(\%)$ & $\begin{aligned} & 78.41^{\mathrm{a}} \\
\pm & 1.75\end{aligned}$ & $\begin{aligned} & 77.00^{\mathrm{ab}} \\
\pm & 1.49\end{aligned}$ & $\begin{aligned} & 75.47^{\mathrm{ab}} \\
\pm & 3.08\end{aligned}$ & $\begin{aligned} & 74.38^{\mathrm{b}} \\
\pm & 1.66\end{aligned}$ & $\begin{aligned} & 76.18^{\mathrm{a}} \\
\pm & 2.89\end{aligned}$ & 0.36 & $<0.05$ \\
\hline \multicolumn{8}{|l|}{ Weight and proportion in carcass } \\
\hline Neck with skin (g) & $\begin{array}{r}90.18^{\mathrm{b}} \\
\pm 16.23\end{array}$ & $\begin{array}{c}120.28^{\mathrm{a}} \\
\pm 11.18\end{array}$ & $\begin{array}{c}124.34^{\mathrm{a}} \\
\pm 16.20\end{array}$ & $\begin{array}{c}120.86^{\mathrm{a}} \\
\pm 12.35\end{array}$ & $\begin{array}{c}126.86^{\mathrm{a}} \\
\pm 13.25\end{array}$ & 2.69 & $<0.05$ \\
\hline Neck with skin $(\%)$ & $\begin{aligned} & 5.22 \\
\pm & 0.92\end{aligned}$ & $\begin{aligned} & 5.04 \\
\pm & 0.52\end{aligned}$ & $\begin{array}{l}5.30 \\
\pm 0.52\end{array}$ & $\begin{aligned} & 5.01 \\
\pm & 0.52\end{aligned}$ & $\begin{aligned} & 5.40 \\
\pm & 0.62\end{aligned}$ & 0.09 & NS \\
\hline Wings (g) & $\begin{array}{c}151.66^{\mathrm{b}} \\
\pm 12.38\end{array}$ & $\begin{array}{l}213.41^{\mathrm{a}} \\
\pm 18.48\end{array}$ & $\begin{array}{c}204.54^{\mathrm{a}} \\
\pm 29.56\end{array}$ & $\begin{array}{c}214.72^{\mathrm{a}} \\
\pm 13.67\end{array}$ & $\begin{array}{c}212.72^{\mathrm{a}} \\
\pm 16.34\end{array}$ & 4.31 & $<0.05$ \\
\hline Wings (\%) & $\begin{aligned} & 8.78 \\
\pm & 0.79\end{aligned}$ & $\begin{array}{r}8.92 \\
\pm 0.64\end{array}$ & $\begin{array}{r}8.70 \\
\pm 0.81\end{array}$ & $\begin{array}{r}8.89 \\
\pm 0.55\end{array}$ & $\begin{array}{l}\quad 9.03 \\
\pm 0.53\end{array}$ & 0.09 & NS \\
\hline Heart $(\mathrm{g})$ & $\begin{aligned} & 8.03^{\mathrm{b}} \\
\pm & 0.92\end{aligned}$ & $\begin{aligned} & 12.73^{\mathrm{a}} \\
\pm & 1.51\end{aligned}$ & $\begin{aligned} & 12.33^{\mathrm{a}} \\
\pm & 1.87\end{aligned}$ & $\begin{aligned} & 13.62^{\mathrm{a}} \\
\pm & 2.53\end{aligned}$ & $\begin{aligned} & 11.69^{\mathrm{a}} \\
\pm & 1.17\end{aligned}$ & 0.36 & $<0.05$ \\
\hline Stomach $(\mathrm{g})$ & $\begin{aligned} & 29.19 \\
\pm & 6.11\end{aligned}$ & $\begin{array}{c}35.51 \\
\pm 5.21\end{array}$ & $\begin{array}{r}36.76 \\
\pm 10.20\end{array}$ & $\begin{aligned} & 35.35 \\
\pm & 4.70\end{aligned}$ & $\begin{aligned} & 38.51 \\
\pm & 9.56\end{aligned}$ & 1.11 & NS \\
\hline Liver $(\mathrm{g})$ & $\begin{aligned} & 39.67^{\mathrm{b}} \\
\pm & 7.30\end{aligned}$ & $\begin{aligned} & 57.66^{\mathrm{a}} \\
\pm & 6.05\end{aligned}$ & $\begin{aligned} & 57.11^{\mathrm{a}} \\
\pm & 10.12\end{aligned}$ & $\begin{aligned} & 62.04^{\mathrm{a}} \\
\pm & 10.32\end{aligned}$ & $\begin{array}{r}60.85^{\mathrm{a}} \\
\pm 10.24\end{array}$ & 1.68 & $<0.05$ \\
\hline Carcass remains (g) & $\begin{array}{r}457.11^{\mathrm{b}} \\
\pm 68.97\end{array}$ & $\begin{array}{c}603.48^{\mathrm{a}} \\
\pm 73.31\end{array}$ & $\begin{array}{c}587.96^{\mathrm{a}} \\
\pm 68.37\end{array}$ & $\begin{array}{c}660.02^{\mathrm{a}} \\
\pm 80.61\end{array}$ & $\begin{array}{r}586.65^{\mathrm{a}} \\
\pm 51.68\end{array}$ & 13.36 & $<0.05$ \\
\hline
\end{tabular}

a,b..., means in the same line with no common superscript differ between groups $(p<0.05)$; NS, no significance; \pm SD, standard deviation; SEM, standard error of the mean for all data; ${ }^{1}, 1$, no addition of aluminosilicates to feed or litter; $2,0.800 \mathrm{~kg} / \mathrm{m}^{2}$ of halloysite in litter; 3 , $0.400 \mathrm{~kg} / \mathrm{m}^{2}$ of halloysite and $0.400 \mathrm{~kg} / \mathrm{m}^{2}$ of zeolite in litter; $4,0.800 \mathrm{~kg} / \mathrm{m}^{2}$ of zeolite in litter; $5,0.200 \mathrm{~kg} / \mathrm{m}^{2}$ of halloysite and $0.600 \mathrm{~kg} / \mathrm{m}^{2}$ of zeolite in litter; groups 2-5, addition of halloysite and zeolite to feed (proportion 25:75; starter, 0.5\%; grower 1, 1\%; grower 2, $1.5 \%$; finisher, $2 \%)$

proportion (400 $\mathrm{g}$ per $\mathrm{m}^{2}$ ) and in feed (25:75 ratio, 0.5-2\%) compared to groups 1,2 and $5(p<0.05)$. Yellowness $\left(b^{*}\right)$ of breast muscles was significantly lower in group 3 than in group $2(p<0.05)$. In the control group (1), water loss from breast muscles was significantly lower compared to experimental groups $(p<0.05)$. The content of protein in breast muscles differed significantly between groups, and in group 5 it was much lower compared to group 1. The content of collagen and salt in group 4 and the content of intramuscular fat and water in group 5 were significantly higher than in groups 1,2 and $3(p<0.05)$ (Table 6).

The analysis of data on the physicochemical characteristics of leg muscles (Table 6) in group 4 revealed a significantly higher redness $\left(\mathrm{a}^{*}\right)$ than in group 1 , while in group 3 the loss of water (water-holding capacity) was significantly lower than in groups 1 and $5(p<0.05)$. In the group of chicken where $800 \mathrm{~g}$ of halloysite per $\mathrm{m}^{2}$ (2) was used, the content of protein in leg muscles was significantly higher compared to other groups of broiler chickens. The content of intramuscular fat in leg muscles from the control group was significantly higher compared to other groups, and the content of water was higher in group $5(p<0.05)$. No significant differences in other parameters were found between groups $(p>0.05)$.

\section{Discussion}

A diet supplemented with natural zeolites (clinoptilolite) at the levels of 15 and $25 \mathrm{~g} / \mathrm{kg}$ of feed had no significant effect on feed intake, body weight gain or feed conversion ratio in broiler chickens, while in the group where $25 \mathrm{~g}$ of zeolite per $\mathrm{kg}$ of feed was used feed intake was lower compared to the control group (Oguz and Kurtoglu 2000). No differences in body weight gain or in the feed conversion ratio were found in broiler chickens fed a diet with the addition of hydrated aluminosilicates at the level of $5 \mathrm{~g} / \mathrm{kg}$ of feed in a study by Prvulovic et al. (2008). In our study, supplemental aluminosilicates also had no effect on the feed conversion ratio, but feed intake was significantly higher in experimental groups compared to the control group, and body weight and its gains were greater in the groups where aluminosilicates were used. Karamanlis et al. (2008) also reported a positive effect of zeolites in feed and litter on the growth performance of 
Table 5 Content of muscles and fat in broiler chicken carcass

\begin{tabular}{|c|c|c|c|c|c|c|c|}
\hline \multirow{2}{*}{$\begin{array}{l}\text { Item } \\
\mathrm{n}=10\end{array}$} & \multicolumn{5}{|l|}{ Group1 } & \multirow[t]{2}{*}{ SEM } & \multirow[t]{2}{*}{ Significance } \\
\hline & 1 & 2 & 3 & 4 & 5 & & \\
\hline \multicolumn{8}{|l|}{ Weight and proportion in carcass } \\
\hline \multirow[t]{2}{*}{ Breast muscles (g) } & $512.89 b$ & $783.22 \mathrm{a}$ & $771.18 \mathrm{a}$ & $743.38 \mathrm{a}$ & $725.59 \mathrm{a}$ & 16.64 & $<0.05$ \\
\hline & \pm 67.91 & \pm 34.54 & \pm 58.76 & \pm 64.97 & \pm 84.72 & & \\
\hline \multirow[t]{2}{*}{ Breast muscles (\%) } & $29.52 b$ & $32.78 \mathrm{a}$ & $32.92 \mathrm{a}$ & $30.73 \mathrm{ab}$ & $30.76 \mathrm{ab}$ & 0.32 & $<0.05$ \\
\hline & \pm 2.01 & \pm 1.21 & \pm 1.37 & \pm 1.74 & \pm 2.84 & & \\
\hline \multirow[t]{2}{*}{ Leg muscles $(\mathrm{g})$} & $374.08 \mathrm{~b}$ & $491.91 \mathrm{a}$ & $489.65 a$ & $508.96 \mathrm{a}$ & $521.55 \mathrm{a}$ & 10.11 & $<0.05$ \\
\hline & \pm 50.09 & \pm 30.19 & \pm 73.53 & \pm 43.75 & \pm 39.07 & & \\
\hline \multirow[t]{2}{*}{ Leg muscles (\%) } & 21.56 & 20.61 & 20.80 & 21.08 & 22.16 & 0.25 & NS \\
\hline & \pm 1.90 & \pm 1.56 & \pm 1.74 & \pm 1.78 & \pm 1.62 & & \\
\hline \multirow[t]{2}{*}{ Total muscles (g) } & $886.97 b$ & $1275.13 \mathrm{a}$ & $1260.83 a$ & $1252.34 \mathrm{a}$ & $1247.14 \mathrm{a}$ & 25.06 & $<0.05$ \\
\hline & \pm 105.87 & \pm 47.13 & \pm 121.99 & \pm 94.07 & \pm 101.87 & & \\
\hline \multirow[t]{2}{*}{ Total muscles (\%) } & 51.08 & 53.40 & 53.72 & 51.81 & 52.92 & 0.37 & NS \\
\hline & \pm 2.63 & \pm 2.23 & \pm 1.50 & \pm 2.77 & \pm 3.18 & & \\
\hline \multirow[t]{2}{*}{ Skin with subcutaneous fat (g) } & $163.78 b$ & $199.92 \mathrm{a}$ & $196.32 \mathrm{a}$ & $191.27 \mathrm{ab}$ & $205.85 \mathrm{a}$ & 4.06 & $<0.05$ \\
\hline & \pm 20.31 & \pm 19.52 & \pm 27.14 & \pm 17.86 & \pm 26.34 & & \\
\hline \multirow[t]{2}{*}{ Skin with subcutaneous fat (\%) } & $9.43 \mathrm{a}$ & $8.36 \mathrm{ab}$ & $8.41 \mathrm{ab}$ & $7.92 b$ & $8.73 \mathrm{ab}$ & 0.14 & $<0.05$ \\
\hline & \pm 0.60 & \pm 0.67 & \pm 1.29 & \pm 0.71 & \pm 0.94 & & \\
\hline \multirow[t]{2}{*}{ Abdominal fat (g) } & 20.58 & 23.56 & 22.22 & 25.30 & 22.92 & 1.25 & NS \\
\hline & \pm 6.30 & \pm 11.53 & \pm 6.33 & \pm 7.72 & \pm 11.70 & & \\
\hline \multirow[t]{2}{*}{ Abdominal fat (\%) } & 1.17 & 0.98 & 0.95 & 1.04 & 0.98 & 0.05 & NS \\
\hline & \pm 0.31 & \pm 0.46 & \pm 0.26 & \pm 0.29 & \pm 0.50 & & \\
\hline \multirow[t]{2}{*}{ Total fat (g) } & $184.36 \mathrm{~b}$ & $223.48 \mathrm{a}$ & $218.54 \mathrm{ab}$ & $216.57 \mathrm{ab}$ & $228.77 \mathrm{a}$ & 4.07 & $<0.05$ \\
\hline & \pm 25.10 & \pm 22.80 & \pm 24.26 & \pm 23.72 & \pm 29.24 & & \\
\hline \multirow[t]{2}{*}{ Total fat (\%) } & $10.60 \mathrm{a}$ & $9.34 \mathrm{ab}$ & $9.35 \mathrm{ab}$ & $8.96 \mathrm{~b}$ & $9.71 \mathrm{ab}$ & 0.15 & $<0.05$ \\
\hline & \pm 0.73 & \pm 0.72 & \pm 1.14 & \pm 0.89 & \pm 1.11 & & \\
\hline
\end{tabular}

a,b..., means in the same line with no common superscript differ between groups $(p<0.05)$; NS, no significance; \pm SD, standard deviation; $\mathrm{SEM}$, standard error of the mean for all data; ${ }^{1}, 1$, no addition of aluminosilicates to feed or litter; $2,0.800 \mathrm{~kg} / \mathrm{m}^{2}$ of halloysite in litter; 3 , $0.400 \mathrm{~kg} / \mathrm{m}^{2}$ of halloysite and $0.400 \mathrm{~kg} / \mathrm{m}^{2}$ of zeolite in litter; $4,0.800 \mathrm{~kg} / \mathrm{m}^{2}$ of zeolite in litter; $5,0.200 \mathrm{~kg} / \mathrm{m}^{2}$ of halloysite and $0.600 \mathrm{~kg} / \mathrm{m}^{2}$ of zeolite in litter; groups 2-5, addition of halloysite and zeolite to feed (proportion 25:75; starter, 0.5\%; grower 1, 1\%; grower 2, $1.5 \%$; finisher, $2 \%)$

chickens, and even on the quality of their litter. The differences in the obtained results could be caused by the different proportions of specific types of aluminosilicates and their form, as well as the method of application (in feed and/or litter), and even the type of litter used in the production of broiler chickens. Higher feed intake is associated with higher body weight, and the positive effect of aluminosilicates on performance parameters may depend on the reduced levels of toxic substances present in the farm building or even in the feed (Al-Nasser et al. 2011). Another study revealed that halloysite reduces the contamination of feed (Kulok et al. 2005).

A study investigating the effect of $1-1.5 \%$ of sodium bentonite or calcium bentonite found no significant effect on broiler chicken carcass traits (Khanedar et al. 2012). Similarly, nanostructured bentonite did not influence chicken carcass traits, apart from an increased proportion of abdominal fat, but it reduced the negative impact of aflatoxins in feed on growth performance parameters (Keyhani-yazdi et al. 2019). In our study the weight of fat in carcass was higher in groups that received aluminosilicates in feed and $800 \mathrm{~g} / \mathrm{m}^{2}$ halloysite (2), and the combination of two aluminosilicates at the level of 200:600 g/ $\mathrm{m}^{2}$ in litter (5). In group 5, the content of intramuscular fat was higher in breast muscles, but in leg muscles from each experimental group its content was lower compared to the control group. Damiri et al. (2012) reported a positive effect of aluminosilicates on carcass traits in chickens. We found significantly higher weight of breast and leg muscles, but no significant changes in dressing percentage, which indicates that such results were obtained because of body weight gain. Interestingly, the weight of liver was higher in chickens where aluminosilicates were used. The lower weight of liver in birds receiving higher doses of sodium bentonite was associated with binding toxins (Damiri et al. 2012). It can be assumed that in our 
Table 6 Physicochemical parameters of breast and leg muscles from broiler chicken

\begin{tabular}{|c|c|c|c|c|c|c|c|}
\hline \multirow{2}{*}{$\begin{array}{l}\text { Parameter1 } \\
n=10\end{array}$} & \multicolumn{5}{|l|}{ Group1 } & \multirow[t]{2}{*}{ SEM } & \multirow[t]{2}{*}{ Significance } \\
\hline & 1 & 2 & 3 & 4 & 5 & & \\
\hline \multicolumn{8}{|l|}{ Breast muscles } \\
\hline \multirow[t]{2}{*}{ pH15 } & $6.63 \mathrm{a}$ & $6.68 \mathrm{a}$ & $6.34 \mathrm{~b}$ & $6.47 \mathrm{ab}$ & $6.62 \mathrm{a}$ & 0.03 & $<0.05$ \\
\hline & \pm 0.22 & \pm 0.19 & \pm 0.17 & \pm 0.17 & \pm 0.20 & & \\
\hline \multirow[t]{2}{*}{$\mathrm{pH} 24$} & 6.11 & 6.01 & 6.00 & 6.12 & 6.06 & 0.03 & NS \\
\hline & \pm 0.11 & \pm 0.21 & \pm 0.16 & \pm 0.19 & \pm 0.29 & & \\
\hline \multicolumn{8}{|l|}{ Colour2 } \\
\hline \multirow[t]{2}{*}{$\mathrm{L}^{*}$} & 52.39 & 53.92 & 54.85 & 54.15 & 56.59 & 0.81 & NS \\
\hline & \pm 4.75 & \pm 6.92 & \pm 4.19 & \pm 5.43 & \pm 7.08 & & \\
\hline \multirow[t]{2}{*}{$a^{*}$} & 2.21 & 3.07 & 2.53 & 3.10 & 2.57 & 0.20 & NS \\
\hline & \pm 0.93 & \pm 1.30 & \pm 1.57 & \pm 1.84 & \pm 1.38 & & \\
\hline \multirow[t]{2}{*}{$\mathrm{b}^{*}$} & $5.90 \mathrm{ab}$ & $6.43 \mathrm{a}$ & $3.94 \mathrm{~b}$ & $4.37 \mathrm{ab}$ & $4.79 \mathrm{ab}$ & 0.25 & $<0.05$ \\
\hline & \pm 1.51 & \pm 1.84 & \pm 1.77 & \pm 1.49 & \pm 1.27 & & \\
\hline \multirow[t]{2}{*}{ Water-holding capacity (\%) } & $20.71 b$ & $29.82 \mathrm{a}$ & $35.44 \mathrm{a}$ & $30.21 \mathrm{a}$ & $33.92 \mathrm{a}$ & 0.91 & $<0.05$ \\
\hline & \pm 5.36 & \pm 2.23 & \pm 2.18 & \pm 4.45 & \pm 4.70 & & \\
\hline \multirow[t]{2}{*}{ Drip loss (\%) } & 0.83 & 0.88 & 1.51 & 1.49 & 1.17 & 0.09 & NS \\
\hline & \pm 0.37 & \pm 0.36 & \pm 0.88 & \pm 0.78 & \pm 0.42 & & \\
\hline \multirow[t]{2}{*}{ Protein $(\%)$} & $23.37 \mathrm{a}$ & $22.67 \mathrm{~b}$ & $22.67 b$ & $21.65 c$ & $20.92 \mathrm{~d}$ & 0.12 & $<0.05$ \\
\hline & \pm 0.10 & \pm 0.08 & \pm 0.09 & \pm 0.04 & \pm 0.04 & & \\
\hline \multirow[t]{2}{*}{ Collagen (\%) } & $0.71 \mathrm{c}$ & $0.84 \mathrm{bc}$ & $0.81 \mathrm{bc}$ & $1.00 \mathrm{a}$ & $0.97 \mathrm{ab}$ & 0.02 & $<0.05$ \\
\hline & \pm 0.18 & \pm 0.10 & \pm 0.12 & \pm 0.06 & \pm 0.07 & & \\
\hline \multirow[t]{2}{*}{ Salt (\%) } & $0.20 \mathrm{c}$ & $0.18 \mathrm{c}$ & $0.27 \mathrm{~b}$ & $0.38 \mathrm{a}$ & $0.26 \mathrm{~b}$ & 0.01 & $<0.05$ \\
\hline & \pm 0.05 & \pm 0.03 & \pm 0.06 & \pm 0.05 & \pm 0.03 & & \\
\hline \multirow[t]{2}{*}{ Intramuscular fat (\%) } & $2.53 \mathrm{~d}$ & $3.13 b$ & $2.83 \mathrm{c}$ & $2.55 \mathrm{~d}$ & $3.40 \mathrm{a}$ & 0.05 & $<0.05$ \\
\hline & \pm 0.05 & \pm 0.05 & \pm 0.03 & \pm 0.02 & \pm 0.01 & & \\
\hline \multirow[t]{2}{*}{ Water (\%) } & $73.78 \mathrm{e}$ & $73.90 \mathrm{~d}$ & $74.38 \mathrm{c}$ & $75.45 \mathrm{a}$ & $75.07 \mathrm{~b}$ & 0.09 & $<0.05$ \\
\hline & \pm 0.08 & \pm 0.07 & \pm 0.06 & \pm 0.03 & \pm 0.07 & & \\
\hline \multicolumn{8}{|l|}{ Leg muscles } \\
\hline \multicolumn{8}{|l|}{ Colour } \\
\hline \multirow[t]{2}{*}{$\mathrm{L}^{*}$} & 49.06 & 50.39 & 51.80 & 47.74 & 51.04 & 0.61 & NS \\
\hline & \pm 3.15 & \pm 4.02 & \pm 3.39 & \pm 4.05 & \pm 6.08 & & \\
\hline$a^{*}$ & $2.52 \mathrm{~b}$ & $3.62 \mathrm{ab}$ & $4.02 \mathrm{ab}$ & $4.96 \mathrm{a}$ & $3.28 \mathrm{ab}$ & 0.21 & $<0.05$ \\
\hline & \pm 1.04 & \pm 1.01 & \pm 1.09 & \pm 1.36 & \pm 1.87 & & \\
\hline$b^{*}$ & 5.01 & 4.48 & 3.89 & 3.50 & 3.55 & 0.24 & NS \\
\hline & \pm 1.86 & \pm 1.39 & \pm 1.78 & \pm 1.10 & \pm 1.26 & & \\
\hline Water-holding capacity (\%) & $38.61 \mathrm{a}$ & $33.48 \mathrm{ab}$ & $28.52 b$ & $37.41 \mathrm{ab}$ & $36.69 \mathrm{a}$ & 0.95 & $<0.05$ \\
\hline & \pm 6.03 & \pm 1.27 & \pm 9.09 & \pm 2.61 & \pm 6.62 & & \\
\hline Protein $(\%)$ & $19.08 \mathrm{bc}$ & $19.46 \mathrm{a}$ & $18.98 \mathrm{bcd}$ & $18.93 \mathrm{~d}$ & $19.07 \mathrm{bc}$ & 0.03 & $<0.05$ \\
\hline & \pm 0.05 & \pm 0.06 & \pm 0.13 & \pm 0.02 & \pm 0.06 & & \\
\hline Collagen $(\%)$ & 1.18 & 1.05 & 1.31 & 1.28 & 1.07 & 0.03 & NS \\
\hline & \pm 0.07 & \pm 0.41 & \pm 0.08 & \pm 0.06 & \pm 0.04 & & \\
\hline Salt $(\%)$ & 0.33 & 0.36 & 0.33 & 0.37 & 0.36 & 0.01 & NS \\
\hline & \pm 0.05 & \pm 0.08 & \pm 0.07 & \pm 0.03 & \pm 0.07 & & \\
\hline Intramuscular fat (\%) & $8.49 \mathrm{a}$ & $7.11 \mathrm{c}$ & $7.99 \mathrm{~b}$ & $6.97 \mathrm{c}$ & $5.93 \mathrm{~d}$ & 0.13 & $<0.05$ \\
\hline & \pm 0.44 & \pm 0.04 & \pm 0.07 & \pm 0.04 & \pm 0.02 & & \\
\hline Water $(\%)$ & $71.38 \mathrm{e}$ & $72.56 \mathrm{c}$ & $72.15 \mathrm{~d}$ & $73.14 \mathrm{~b}$ & $74.17 \mathrm{a}$ & 0.13 & $<0.05$ \\
\hline & \pm 0.05 & \pm 0.11 & \pm 0.08 & \pm 0.09 & \pm 0.11 & & \\
\hline
\end{tabular}

a,b..., means in the same line with no common superscript differ between groups $(p<0.05)$; NS, no significance; \pm SD, standard deviation; SEM, standard error of the mean for all data; ${ }^{1}, 1$, no addition of aluminosilicates to feed or litter; $2,0.800 \mathrm{~kg} / \mathrm{m}^{2}$ of halloysite in litter; 3 , $0.400 \mathrm{~kg} / \mathrm{m}^{2}$ of halloysite and $0.400 \mathrm{~kg} / \mathrm{m}^{2}$ of zeolite in litter; $4,0.800 \mathrm{~kg} / \mathrm{m}^{2}$ of zeolite in litter; $5,0.200 \mathrm{~kg} / \mathrm{m}^{2}$ of halloysite and $0.600 \mathrm{~kg} / \mathrm{m}^{2}$ of zeolite in litter; groups 2-5, addition of halloysite and zeolite to feed (proportion 25:75; starter, 0.5\%; grower 1, 1\%; grower 2, $1.5 \%$; finisher, $2 \%){ }^{2}, \mathrm{~L}^{*}$, lightness; $\mathrm{a}^{*}$, redness; $\mathrm{b}^{*}$, yellowness 
study the level and type of supplemental aluminosilicates influenced the quality of feed. Other factors to consider include the chemical composition of feed, as well as the metabolism of lipids and their accumulation in the liver (Karimirad et al. 2020).

A comparison of our findings on the $\mathrm{pH}$ of breast muscles with data reported by Qiao et al. (2001) leads to the conclusion that the $\mathrm{pH}$ of muscles was optimal in all groups of chickens, and the obtained meat should be regarded as normal, but the value of lightness $\left(\mathrm{L}^{*}\right)$ indicates that meat colour was between light and normal. According to Hertanto et al (2018), tissue acidification values between $5.81-6.30$ are for normal meat. However, after $24 \mathrm{~h}$, the meat should have a pH close to 6.00. Consistently with our study, Hashemi et al. (2014) demonstrated that the addition of zeolite was associated with a greater loss of water from breast muscles and leg muscles. Our research revealed a positive effect of zeolite and halloysite in litter $(400 \mathrm{~g} / \mathrm{kg}$ for both) and in feed $(0.5-2 \%)$ on water-holding capacity of leg muscles. Meat quality parameters (including WHC) and the chemical composition of muscles may depend on protein oxidation (Zhang et al. 2013) and nutrients used for the preparation of feed (Olfati et al. 2020).

The effects of aluminosilicates were also investigated in laying hens and other animal species. Improved quality of eggs (Skiba et al. 2009), and positive effect on fatty acid composition in pigs were found (Korniewicz et al. 2006), but also the positive effect of zeolite on the quality of meat from broiler chickens and halloysite in feed and litter on the intestinal morphology (Banaszak et al. 2020).

Summing up, the results obtained in the experimental groups where we used halloysite and zeolite in a 25:75 ratio in feed at the level of $0.5-2 \%$ in different feeding phases (starter, grower 1 and 2, finisher) and in litter (chopped rye straw) at different levels and proportions $\left(2,0.800 \mathrm{~kg} / \mathrm{m}^{2}\right.$ of halloysite in litter; $3,0.400 \mathrm{~kg} / \mathrm{m}^{2}$ of halloysite and $0.400 \mathrm{~kg} /$ $\mathrm{m}^{2}$ of zeolite in litter; $4,0.800 \mathrm{~kg} / \mathrm{m}^{2}$ of zeolite in litter; 5 , $0.200 \mathrm{~kg} / \mathrm{m}^{2}$ of halloysite and $0.600 \mathrm{~kg} / \mathrm{m}^{2}$ of zeolite in litter) indicated that these aluminosilicates can improve body weight gain without increasing feed conversion ratio. We also found no negative effect of aluminosilicates on most of the analysed physicochemical parameters of meat or the quality of breast and leg muscles, except the water-holding capacity of breast muscles. Importantly, the use of the proposed aluminosilicates was associated with higher proportion of muscles in chicken carcass. In practice, aluminosilicates in poultry production could increase the live body weight of birds, which is one of the most important aspects from the producers' point of view.
Acknowledgements The authors thank the Kuyavian-Pomeranian Association of Poultry Breeders and Egg Producers (Poland) (www. bezpiecznaferma.pl) for the opportunity to conduct research and implement their results for further poultry management practice, as well as the Agency for the Restructuring and Modernisation of Agriculture (Poland; founder of project).

Authors' contributions All authors took part in meat quality analysis. M.B. - design of experiment, M.B., J.B. analysed physicochemical traits, M.B., J.B. analysed chemical traits in breast muscles, M.B., M.A. analysed data, M.B., J.B., M.A wrote the paper in cooperation with all of the authors. All authors approved the final manuscript.

Funding This research was funded by the project "Safe Farm - innovative products, processes and marketing in the production of broiler chickens", implemented in 2020-2022 and co-financed from the European Agricultural Fund for Rural Development: Europe investing in rural areas".

Data availability The datasets generated and analyzed during the current study are not publicly available due to all the results in the form of means and statistics are presented in this paper, but are available from the corresponding author on reasonable request.

Code availability Not applicable.

\section{Declarations}

Ethics statement The study concerned the analysis of physicochemical characteristics of meat quality obtained from broiler chickens managed on a commercial farm. Growth performance was controlled by the farm owner with cooperation from the research team. Therefore, according to Directive no. 2010/63/EU, the study did not require approval from a Local Ethics Committee. No approval was required under Resolution no. 13/2016 of the National Ethics Committee for Animal Experiments of 17 June 2016. Slaughter of birds was done according to the Council Regulation (EC) No 1099/2009 of 24 September 2009 on the protection of animals at the time of the killing. All methods in the presented experiment were carried out in accordance with relevant guidelines and regulations.

Consent to participate Authors have permission to participate.

Consent for publication Authors have permission for publication.

Competing interests The authors declare that they have no conflicts of interest.

Open Access This article is licensed under a Creative Commons Attribution 4.0 International License, which permits use, sharing, adaptation, distribution and reproduction in any medium or format, as long as you give appropriate credit to the original author(s) and the source, provide a link to the Creative Commons licence, and indicate if changes were made. The images or other third party material in this article are included in the article's Creative Commons licence, unless indicated otherwise in a credit line to the material. If material is not included in the article's Creative Commons licence and your intended use is not permitted by statutory regulation or exceeds the permitted use, you will need to obtain permission directly from the copyright holder. To view a copy of this licence, visit http://creativecommons.org/licenses/by/4.0/. 


\section{References}

Al-Nasser AY, Al-Zenki SF, Al-Saffar AE, Abdullah FK, Al-Bahouh ME, Mashaly M (2011) Zeolite as a feed additive to reduce Salmonella and improve production performance in broilers. Int $\mathbf{J}$ Poult Sci 10:448-454

Andronikashvili TG, Urushadze TF, Eprikashvili LG, Kordzakhia TN, Zautashvili MG, Pirtzkhalava NV, Dzagania MA (2014) Natural zeolites in poultry farming. Ann Agra Sci 12:1-17

Aviagen (2015) Kieszonkowy podręcznik. [Online] Ross Avn Aviagen Brand, 1-60. Available: www.aviagen.com. Accessed 28 May 2021

Banaszak M, Biesek J, Bogucka J, Dankowiakowska A, Olszewski D, Bigorowski B, Grabowicz M, Adamski M (2020) Impact of aluminosilicates on productivity, carcass traits, meat quality, and jejunum morphology of broiler chickens. Poult Sci 99:7169-7177. https://doi. org/10.1016/j.psj.2020.08.073

Biesek J, Banaszak M, Adamski M (2021) Ducks' growth, meat quality, bone strength, and jejunum strength depend on zeolite in feed and long-term factors. Animals 11:1015. https://doi.org/10.3390/ani11 041015

Biesek J, Kuźniacka J, Banaszak M, Maiorano G, Grabowicz M, Adamski M (2020) The effect of various protein sources in goose diets on meat quality, fatty acid composition, and cholesterol and collagen content in breast muscles. Poult Sci 99:6278-6286. https://doi.org/ 10.1016/j.psj.2020.08.074

Damiri H, Chaji M, Bojarpour M, Mamuei M (2012) Effect of different sodium bentonite levels on performance, carcass traits and passage rate of broilers. Pak Vet J 32:197-200

Hafez HM, Attia YA (2020) Challenges to the poultry industry: current perspectives and strategic future after the COVID-19 outbreak. Front Vet Sci 7:516. https://doi.org/10.3389/fvets.2020.00516

Haque MdH, Sarker S, Islam MdS, Islam MdA, Karim MdR, Kayesh MEH, Shiddiky MJA, Answer MS (2020) Sustainable antibiotic-free broiler meat production: current trends, challenges, and possibilities in a developing country perspective. Biology 9:411. https://doi.org/ 10.3390/biology9110411

Hashemi SR, Davoodi D, Dastar B, Bolandi N, Smaili M, Mastani R (2014) Meat quality attributes of broiler chickens fed diets supplemented with silver nanoparticles coated on zeolite. Poult Sci J 2:183-193. https://doi.org/10.22069/PSJ.2014.1965

Hertanto BS, Nurmalasari CDA, Nuhriawangsa AMP, Cahyadi M, Kartikasari LR (2018) The physical and microbiological quality of chicken meat in the different type of enterprise poultry slaughterhouse: a case study in Karanganyar District. International Symposium on Food and Agro-biodiversity (ISFA). IOP Conf. Series: Earth and Environmental Science 102:012051

Huff WE, Kubena LF, Harvey RB, Philips TD (1992) Efficacy of hydrated sodium calcium aluminosilicate to reduce the individual and combined toxicity of aflatoxin and ochratoxin A. Poult Sci 71:64-69

Iannetti L, Neri D, Torresi M, Acciari VA, Di Marzio V, Centorotola G, Scattolini S, Pomilio F, Di Giannatale E, Podaliri Vulpiani M (2020) Can animal welfare have an impact on food safety? A study in the poultry production chain. Europ J Public Health 30(ckaa166):202. https://doi.org/10.1093/eurpub/ckaa166.202

Karamanlis X, Fortomaris P, Arsenos G, Dosis I, Papaioannou D, Batzios C, Kamarianos A (2008) The effect of a natural zeolite (clinoptilolite) on the performance of broiler chickens and the quality of their litter. Asian-Australas J Anim Sci 21:1642-1650

Karimirad R, Khosravinia H, Parizadian Kavan B (2020) Effect of different feed physical forms (pellet, crumble, mash) on the performance and liver health in broiler chicken with and without carbon tetrachloride challenge. J Anim Feed Sci 29:59-66
Keyhani-yazdi H, Hosseini-vashan S, Afzali N, Mojtahedi M, Allahresani A (2019) Effects of Physical Modification of Nanostructure Aluminosilicate on Growth Performance, Carcass Traits and Blood Parameters of Broiler Chicken Challenged with Aflatoxin B1. Iranian J Anim Sci Res 10:489-500.

Khanedar F, Vakili R, Zakizadeh S (2012) Effects of two kinds of bentonite on the performance, blood biochemical parameters, carcass characteristics and tibia ash of broiler chicks. Global Veterinaria 9:720-725. https://doi.org/10.5829/idosi.gv.2012.9.6.61151

Korczyński M, Jankowski J, Wiktowska D, Opaliński S, Szoltysik M, Kołacz R (2013) Use of halloysite and vermiculite for deodorization of poultry fertilizer. Przemysł Chemiczny 92:1027-1031

Korniewicz D, Kołacz R, Dobrzański Z, Korniewicz A, Kulok M (2006) Effect of dietary halloysite on the quality of feed and utilization of nutrients by fatteners. EJPAU 9:59

Kulok M, Kołacz R, Dobrzański Z, Wolska I (2005) The influence of halloysite on the content of bacteria, fungi and mycotoxins in feed mixtures. ISAH 2005 - Warsaw Poland 2:354-257

Martinez L, Ros G, Nieto G (2020) Effect of natural extracts obtained from food industry by-products on nutritional quality and shelf life of chicken nuggets enriched with organic $\mathrm{Zn}$ and Se provided in broiler diet. Poult Sci 99:1491-1501

Mendonca NBSN, Sobrane Filho ST, Oliveira DH, Lima E, Rosa P, Faria PB, Naves LP, Rodrigues PB (2020) Dietary chia (Salvia hispanica L.) improves the nutritional quality of broiler meat. Asian-Asutralas J Anim Sci 33:1310-1322

Oguz H, Kurtoglu V (2000) Effect of clinoptilolite on performance of broiler chickens during experimental aflatoxicosis. Br Poult Sci 41:512-517

Olfati Z, Shariatmadari F, Karimi Torshizi MA, Ahmadi H, Sharafi M, Bedford MR (2020) Effects of partial replacement of soybean meal in broiler diets with gelatin and mono-component protease on growth performance, carcass and blood biochemical characteristics, lipid oxidation of meat, and economics. Anim Prod Sci 61:146-155

Prvulovic D, Kojic D, Grubor-Lajsic G, Kosarcic S (2008) The effects of dietary inclusion of hydrated aluminosilicate on performance and biochemical parameters of broiler chickens. Turk J Vet Anim Sci 32:183-189

Qiao M, Fletcher DL, Smith DP, Northcutt JK (2001) The effect of broiler breast meat color on ph, moisture, water-holding capacity, and emulsification capacity. Poult Sci 80:676-680

Roth N, Kasbohrer A, Mayrhofer S, Zitz U, Hofacre C, Doming KJ (2019) The application of antibiotics in broiler production and the resulting antibiotic resistance in Escherichia coli: A global overview. Poult Sci 98:1791-1804

Schneider AF, De Almeida DS, Yuri FM, Zimmermann OF, Gerber MW, Gewehr CE (2006) Natural zeolites in diet or litter of broilers. $\mathrm{Br}$ Poult Sci 57:257-263

Schneider AF, Zimmermann OF, Gewehr CE (2017) Zeolites in poultry and swine production. Cienc Rural 47:e20160344. https://doi.org/ 10.1590/0103-8478cr20160344

Selaledi LA, Hassan ZM, Manyelo TG, Mabelebele M (2020) The current status of the alternative use to antibiotics in poultry production: an african perspective. Antibiotics 9:594. https://doi.org/10.3390/antib iotics 9090594

Shariatmadari $\mathrm{F}$ (2008) The application of zeolite in poultry production. World's Poult Sci J 65:76-84

Skiba M, Kulok M, Kołacz R, Skiba T (2009) The influence of halloysite supplementation in laying hens feeding on egg yolk lipid fraction. In World Poultry Science Association, Proceedings of the 19th European Symposium on Quality of Poultry Meat, 13th European Symposium on the Quality of Eggs and Egg Products, Turku, Finland, 21-25 June 2009; World's 
Poultry Science Association (WPSA): Beekbergen, The Netherlands : $1-9$

STATISTICA PL (2017) Version 13.3, Statsoft Poland, TIBCO Software Inc., Cracow, Poland. https://www.statsoft.pl/. Accessed 25 April 2021

Wlazło Ł, Nowakowicz-Dębek B, Kapica J, Kwiecień M, Pawlak H (2016) Removal of ammonia from poultry manure by aluminosilicates. J Environment Management 183:722-725
Xing T, Zhao X, Zhang L, Li JL, Zhou GH, Xu XL, Gao F (2020) Characteristics and incidence of broiler chicken wooden breast meat under commercial conditions in China. Poult Sci 99:620-628

Zhang W, Marwan AH, Samaraweera H, Lee EJ, Ahn DU (2013) Breast meat quality of broiler chickens can be affected by managing the level of nitric oxide. Poult Sci 92:3044-3049

Publisher's note Springer Nature remains neutral with regard to jurisdictional claims in published maps and institutional affiliations. 